Article

\title{
Lights and Shadows of Business-Nonprofit Partnerships: The Role of Nonprofit Learning and Empowerment in this Ethical Puzzle
}

\author{
María José Sanzo ${ }^{1}$ (D), Luis Ignacio Álvarez ${ }^{1}$ (D) and Marta Rey ${ }^{2, *}$ \\ 1 Facultad de Economía y Empresa, Universidad de Oviedo, Avda. del Cristo, s/n 33071 Oviedo, Asturias, \\ Spain; mjsanzo@uniovi.es (M.J.S.); alvarezg@uniovi.es (L.I.Á.) \\ 2 Facultad de Economía y Empresa, Universidade da Coruña, Campus de Elviña, 15071 A Coruña, Spain \\ * Correspondence: mjsanzo@uniovi.es; Tel.: +34-985-102-824
}

Received: 17 July 2017; Accepted: 7 August 2017; Published: 10 August 2017

\begin{abstract}
Business-nonprofit partnerships have gained increased relevance in the context of the evolution of corporate social responsibility strategies and the existence of extremely complex societal and environmental challenges. However, these collaborations are also associated with important ethical concerns. Under such a scenario, this study attempts to shed light on the effects of high value-added partnerships-i.e., those characterized by a process of nonprofit empowerment-on two potential risks of business-nonprofit partnerships: co-optation and loss of personnel's identification with the nonprofit's social mission. Based on a two-step survey to a representative sample of Spanish nonprofits involved in social partnerships with firms, results reveal the existence of a mixed influence in both cases, positive and negative. Several implications for practitioners are drawn, specifically about how firms and nonprofits can reduce the negative ethical consequences of partnering.
\end{abstract}

Keywords: business-nonprofit partnerships; corporate social responsibility; nonprofit empowerment; co-optation; personnel's identification with the nonprofit mission

\section{Introduction}

The research on cross-sector partnerships, i.e., alliances in which firms, governments, and civil society actors cooperate to address social and environmental causes, has received a great amount of attention during the last few decades [1-7]. The increasingly complex problems these partnerships address, their implications for sustainable development, and the ethical dilemmas that characterize the interactions among the three sectors suggest its growing relevance for both practitioners and scholars from various academic disciplines, including sustainability. Particularly, new forms of collaboration between businesses and nonprofits have emerged, characterized by going beyond their conventional roles of donor and beneficiary and generating other shared value-added resources and capabilities for the business organization, the nonprofit and society.

The importance of nonprofits for firms' Corporate Social Responsibility (CSR) initiatives results from two main factors. The first one is their growing contribution to the well-being of societies in terms of healthcare, education, culture, social services, environmental or human rights protection. The second factor refers to the relevance of social innovation in current societies as a crucial factor for fostering sustainable growth. This kind of innovation becomes more important in the areas where commercial and existing public sector organizations have failed. It is precisely in these areas that the nonprofit sector has emerged as a basic source of social innovation activities. However, although there seems to be consensus on the fact that "partnership emerges as a potential catalyst of social change" [8] (p. 47), those partnerships involving firms and nonprofit organizations generate serious suspicion, distrust and ethical concerns within the nonprofit sector. 
Specifically, two closely related hazards for nonprofits (and society) are worthy of note. The first potential risk refers to the possibility of co-optation, understood as a process of alignment of the nonprofit's interests with those of the corporation that may compromise the organizational identity, independence and legitimacy of the former [9]. The second downside is associated with the possible loss of personnel's commitment to the social mission of the nonprofit. This is due to the increased professionalization needed to fulfil the control and reporting requirements of corporate partners, resulting in prevalence of a 'managerial identity', based on formalization and efficiency, over a 'volunteer identity', more linked to the achievement of the social mission [10].

However, as business-nonprofit partnerships (BNPP) are a complex and multifaceted phenomenon, it is probable that a particular type of collaboration leads to different and even reverse effects in connection to highly sensitive ethical issues. In this research we argue that the extent to which nonprofits develop, as a consequence of the partnership, a process of organizational learning that provides them with the authority, resources, skills and management techniques needed to proactively make decisions and improve their performance, generates two types of opposite effects.

On the one hand, we expect that the closer ties between nonprofits and firms that are needed to develop this process of learning will boost the nonprofit's identification with the firm and the risk of co-optation, in line with the reasoning provided by Baur and Schmitz [9]. In addition, learning about management techniques will probably improve the professionalization and formalization of the nonprofit and therefore the existence of conflicts between paid employees and volunteers, as Kreutzer and Jäger [10] note, lowering personnel's identification with the values and social mission of the nonprofit. On the other hand, we also anticipate that learning will: (a) empower the nonprofit to act more independently, in such a way that its attitude towards the firm will be more critical and demanding (expressing more divergent opinions and therefore limiting the risk of co-optation); (b) reduce the power imbalance so that nonprofits can influence in a more significant way the behavior of their usually more powerful partners; and (c) improve the nonprofit's skills in managing human resources (showing a more intense orientation towards personnel satisfaction and well-being).

So, based on the ethical aspects of sustainable development as the basic approach, we attempt to offer a twofold contribution to the research agenda on the analysis of the effects of BNPP from the perspective of organizational ethics and sustainability. First, a comprehensive revision of existing literature on cross-sector partnerships [6] shows that previous studies have analyzed typologies of business-nonprofit relationships; partners' motivations; the determinants of a predisposition to cooperate; the drivers of partnership building and the processes involved; organizational structures and governance mechanisms; managerial skills; the effect of power balances or imbalances between partners; and the impact of partnerships on performance, generally on the firm's results. These works are mainly conceptual or based on case studies, with a few exceptions [11-15]. In order to improve insights emerging from them, and following the suggestions provided by Austin and Seitanidi [2] (p. 744), we conduct a quantitative-based research based on a two-step survey to a representative sample of nonprofits involved in BNPP.

Second, although previous studies provide an overview of BNPP, different knowledge gaps demand further inquiry. One of these gaps refers to the ethical consequences of BNPP. We include in the analysis one relevant variable that has been omitted from the debate on the link between BNPP and co-optation/loss of personnel identification with the social mission, i.e., nonprofit empowerment by means of a process of organizational learning. Potential benefits of BNPP for nonprofits include not only 'associational value' (higher visibility, credibility) and 'transferred value' (financial support, in-kind gifts, etc.), but also other types of higher-level value. These higher-level forms of value involve 'interaction value' (opportunities for learning, development of unique capabilities, etc.), and 'synergistic value', such as innovation or sharing leadership [3]. High value-added partnerships represent an interesting context to analyze ethical hazards since their diverse dimensions can simultaneously increase and limit undesirable ethical consequences. 
The presentation of the paper is organized as follows. The 'materials and methods' section describes different types of BNPP based on the 'collaborative value creation' framework [2,3], provides the definitions of empowerment and organizational learning, and addresses the potential consequences of a learning process on co-optation and the loss of personnel's identification with the social mission. We propose in both cases the existence of two opposite effects, derived from two underlying characteristics of what learning means, related to the process itself and its results, respectively. This section also details the two-step methodology we used to carry out the analysis. We developed a quantitative-based research and surveyed a representative sample of Spanish nonprofits. The subsequent sections present the results, discuss the main conclusions and implications, and note the limitations and further research directions.

\section{Materials and Methods}

\subsection{Literature Review}

\subsubsection{Business-Nonprofit Partnerships, Nonprofit Empowerment and Learning}

BNPP have been usually envisioned by firms "as a means to establish credentials of responsible corporate citizenship" [9] (p. 9), and seized by nonprofits as an opportunity for "increased revenue and/or influence" [9] (p. 9). However, new forms of collaboration that extend the simple roles of donor and beneficiary are emerging as a consequence of sectorial blurring. A number of studies have outlined the existence of different types of partnerships according to their position along a 'collaboration continuum' [2,3,16-18]. One of the best known models is the so-called 'collaborative value creation' framework [2,3], which identifies four basic categories of partnerships, i.e., philanthropic, transactional, integrative, and transformational partnerships.

The relationship shows an evolution as it evolves along this continuum $[2,3,15]$. Factors such as its contribution to the partners' missions and strategic value for both organizations, the magnitude of resources involved, the geographical scope of the partnership, the level of engagement, trust and communication between the partners, complexity, and internal and social changes generated as a result of the cooperation, move from low to high levels as the partnership reaches the integrative and, especially, the transformational stage, where different forms of interaction and synergistic value are salient outcomes.

From a corporate viewpoint, value-added partnerships represent a crucial outcome of the latest development of the CSR concept, since "managing the relationship with nongovernmental organizations (NGOs) is a key capability for most companies, because dialogue with stakeholders is a requested feature of Corporate Social Responsibility" [19] (p. 110). As CSR advances from a philanthropic approach, in which firms develop charitable actions not linked to the firm's core business and without seeking direct returns (beyond improved corporate reputation), to an instrumental or utilitarian approach, characterized by a 'strategic philanthropy,' in which firms expect an economic return from CSR strategies more connected to the business, and furthermore to the 'corporate responsibility innovation' [20], which combines improved firm's competitiveness and well-being of communities, CSR adopts a long-term orientation closely intertwined with the social innovation concept [21-23].

The main difference between the instrumental approach and corporate responsibility innovation, understood as a political conception of CSR, is that the former "seeks to identify those specific opportunities where business can gain from a partnership without having to compromise any of their core interests and goals [...] and offers only limited opportunities for NGOs to transform corporate behavior" [9] (p. 16); whereas the latter "puts greater emphasis on one of the original reasons for advancing the CSR agenda, namely, to hold multinational corporations accountable for the increasing power and influence they exercise in their daily decision making" [9] (p. 17).

In other words, "political relationships aim to change business practices, so that companies meet the economic, social and environmental expectations of their stakeholders" [19] (p. 110). Thus, 
the political notion is not afraid of conflict because its aim is "to effectively contribute to the solution of a perceived societal or environmental problem, even if it may not directly contribute to the generation of profits" [9] (p. 17); implying that firms "take on significant responsibilities that likely entail sharing power with local communities and NGOs" [9] (p. 17).

Empowerment, consequently, represents an inherent feature of high value-added partnerships. According to the World Bank's web page [24], it can be defined as "the process of enhancing the capacity of individuals or groups to make choices and to transform those choices into desired actions and outcomes. Central to this process are actions which both build individual and collective assets, and improve the efficiency and fairness of the organizational and institutional context which govern the use of these assets". Four key elements of empowerment in practice are: (1) access to information; (2) inclusion and participation; (3) accountability for actions; and (4) local organizational capacity.

As our research focuses on relationships between two kinds of organizations, empowerment can involve the improvement of skills, resources, and authority of the less powerful partner, as well as holding partners accountable for outcomes of their actions, since BNPP can help social enterprises and nonprofits acquire and develop capabilities [25].

In BNPP the firm is traditionally viewed as the more powerful partner, whereas the nonprofit is the 'beneficiary'. However, this 'donor-recipient' model is dysfunctional in a context of transformational BBNP, since it gives rise to prejudices about the partners' roles and capabilities. Within a transformational BNPP, both partners are donors and recipients at the same time, nonprofit empowerment being a valuable outcome if the objective is to create high value-added solutions. Firms can contribute to this goal by improving the nonprofit's capabilities and professional skills.

Among the different competences and skills that could be related to this empowerment process, the so-called 'dynamic capabilities' play an outstanding role, because they allow organizations to be intensely entrepreneurial and pro-active. Dynamic capabilities include "the capability (1) to sense and shape opportunities and threats; (2) to seize opportunities; and (3) to maintain competitiveness through enhancing, combining, protecting, and, when necessary, reconfiguring the business enterprise's intangible and tangible assets" [26] (p. 1319). Organizational learning represents one of the basic micro foundations of dynamic capabilities [26], so we will focus on this construct as a critical dimension of empowerment.

There is an extensive research on organizational learning, defined as a dynamic process of creating, obtaining, and integrating knowledge to develop resources and capabilities that will allow the organization to achieve better performance [27]. At least three main phases are commonly highlighted: information acquisition, information dissemination, and learning integration/institutionalization/shared interpretation [28-32]. Information can be derived from different sources, both external and internal; BNPP can represent a relevant external source of information for nonprofits about potential targets and networks, unique skills and capabilities, or innovation activities [3].

Specifically, it has been noted that nonprofits show an important deficit in capabilities related to support functions such as administration, finance, information and communication technologies, marketing, and human resources; in which a greater level of professionalization is increasingly demanded [33,34] in order to foster dynamic capabilities. Nonprofit professionalization "involves not being an amateur anymore, showing expertise, skillfully executing organizational tasks, and providing superior services both internally and externally" [35] (p. 25). By means of BNPP, nonprofits can benefit not only from direct support for their social mission, but also "more indirectly [from] access to technical, management, and/or marketing expertise, widening of networks, greater leverage and visibility, and career development and learning opportunities for current and future staff members and volunteers" [36] (p. 227). 


\subsubsection{Nonprofit Empowerment, Co-Optation and Personnel's Identification with the Mission}

Analyzing the effects of BNNP is not an easy task, because the interactions between two types of actors with different (and sometimes conflicting) missions, objectives, cultures, structures and strategies can generate multiple impacts, both positive and negative. So, several research streams and arguments can be used to justify potential consequences of these partnerships. With the aim of integrating the diverse set of arguments and theories that we will employ to develop the hypotheses of our study, the subsequent sections should be understood under the general umbrella of the consequentialist ethical approach. This means that, of the basic ethical frameworks developed to guide ethical decision making (i.e., the "Consequentialist", "Duty", and "Virtue" frameworks), we use the Consequentialist Framework to conceptualize this kind of partnership and as the coherent framework of the research. The decisions and results of this strategy generate different consequences, and directly and indirectly affect many people, some of whom may benefit from the actions, while others may not, being the ethical conduct that action that achieves the most good as a whole.

The Effects of the Process of Learning and Empowerment on Co-Optation

Grounding in critical social theory, co-optation can be defined as the capacity of an organization to "bring the interests of a challenging group into alignment with its own goals" [9] (p. 11), quoted from Trumpy [37] (p. 480), in such a way that "co-opted NGOs are gradually absorbed and their organizational identity is compromised" [9] (p. 11).

The risk of co-optation depends on different factors. The intentions and motives of corporations are an important driver, since firms can collaborate deliberately with nonprofits to "control the fallout of civil society mobilization against their unethical behavior and as a way of controlling or anticipating such actions in the future" [9] (p. 12). Furthermore, co-optation is more likely in those partnerships that create a resource dependency for nonprofits (e.g., sponsorship agreements), involve endorsement of the products of the firm by the nonprofit (e.g., certification or labelling agreements), or involve personal ties between both organizations (e.g., when corporate leaders are hired by nonprofits to face fundraising challenges). All these situations compromise nonprofits' capability to challenge corporate behavior [9].

A process of knowledge transfer and learning may foster the risk of co-optation if we consider that such a process is usually associated with improved flows of communications, closer and personal relationships, and trust in the firm [38-41]. Particularly, Bennett et al. [42] have noted that one of the factors that influences effective knowledge transfer in BNPP is credibility of the source (the degree to which it is perceived as expert, reputable and trustworthy). Similarly, the meta-analysis developed by Barroso-Méndez et al. [43] of a model of success for BNPP shows a strong positive effect of trust on relationship learning.

Therefore, it is likely that the existence of improved personal relationships with and trust in the company will be required to lead to this process of learning. At the end, these closer ties and trusting relationships will boost the development of affective commitment to the firm, since "when individuals develop a personal relationship of trust within the partnership then the level of embeddedness of the relationship becomes more evident" [44] (p. 422). This type of commitment means that an affective and moral predisposition to maintain the relationship exists because the organization develops emotional bonds and shares the partner's values. As a result, the level of identification of the nonprofit with the firm, as well as its loyalty toward the company, are reinforced, involving the partners in emotional, social, moral and physical ways [11,12,45].

The possible consequences of this 'affective' alignment and identification with the firm are that the nonprofit organization: (1) is willing to change its previous culture and strategies, compromising its organizational identity and independence; and (2) may consider that it is not necessary to control the firm's activities thoroughly, compromising its role as advocate or watchdog. Therefore, we posit: 
Hypothesis 1a (H1a). The extent to which a nonprofit develops a process of learning about management techniques as a result of the partnership is positively associated with the nonprofit's affective commitment to the firm.

Hypothesis $\mathbf{1 b}(\mathbf{H} 1 \mathbf{b})$. Nonprofit's affective commitment to the firm is positively associated with the change in the nonprofit's culture and strategies.

Hypothesis 1c (H1c). Nonprofit's affective commitment to the firm is positively associated with the nonprofit's perception that it is not necessary to meticulously control the activities developed by the firm.

However, the result of this process of learning could also lower the risk of co-optation if we take into account that the resulting empowerment should help the nonprofit make choices with autonomy. Particularly, one of the consequences of nonprofit empowerment could be the intensification of its capability to assess the firm's decisions from a professional and technical point of view, which can lead to the appearance and growth of potential discrepancies between both organizations.

Conflict "emerges from the differing aims and expectations that partners bring to a collaboration, from differing views about strategies and tactics, and from attempts to protect or magnify a partner's control over the collaboration's work or outcomes" [46] (p. 48). We can expect those partnerships where nonprofit empowerment does not exist to lead to a situation in which the dependent nonprofit shows more conformity with the firm's decisions, while explicit conflicts and discrepancies tend to be lower. On the contrary, if the nonprofit's management capabilities are developed, then it will become more autonomous in its decision-making process (since the organization will be in a better condition to identify, shape, and seize opportunities and threats), thus limiting the risk of co-optation (as an improved critical attitude will lower the nonprofit's affective commitment to the firm). Following this reasoning, we expect that:

Hypothesis 2a (H2a). The extent to which a nonprofit develops a process of learning about management techniques as a result of the partnership is positively associated with the existence of greater discrepancies between the partners on decisions and strategies.

Hypothesis $\mathbf{2} \mathbf{b}(\mathbf{H} \mathbf{2} \mathbf{b})$. The existence of greater discrepancies between the partners on decisions and strategies is negatively associated with the nonprofit's affective commitment to the firm.

Moreover, under the conventional donor-recipient model characterized by imbalance of power in favor of the corporation, firms are unlikely to perceive the nonprofit's capability to develop innovative products/services, or the possibility that it provides the firm with further resources or capabilities beyond positive effects on corporate reputation [47]. On the contrary, the existence of a process of learning within the nonprofit will probably enhance the firm's perception (and also the nonprofit's own appreciation) about the nonprofit's capability to contribute to partnership success. The explanation for this expected result is related to the fact that one of the major barriers to successful transformational partnerships is power asymmetry. If a process of learning about management skills occurs in the nonprofit, therefore improving its professionalization, it is likely that the perception about the nonprofit shifts from being a 'beneficiary' in a passive role, to being a 'donor' partner too, with the competence to contribute to the partnership and to affect and transform corporate behavior.

As Baur and Schmitz [9] (p. 10) recognize when arguing for the adoption of a political conception of CSR, "collaborating with NGOs in an equal partnership enhances the capacity to solve problems that are relevant to both actors. Furthermore, although the decision to collaborate does not depend on it, such an equal partnership might also provide corporations with a competitive advantage in the market place in the long run." Our hypothesis states that:

Hypothesis 3 (H3). The extent to which a nonprofit develops a process of learning about management techniques as a result of the partnership is positively associated with its capability to transform corporate behavior. 
The Effects of the Process of Learning and Empowerment on Personnel Identification with the Social Mission

Nonprofit's human resources often involve both paid staff and volunteers, and "the difference between 'amateurs' and 'professionals' [...] raises issues that are at the heart of nonprofits' identity and culture" [48] (p. 282), cited by Kreutzer and Jäger [10] (p. 635).

Fierce competition for resources and increased demands for accountability are forcing nonprofits to boost their degree of professionalization by increasing the number of paid professionals and fostering the competences and skills of their personnel [49]. Collaboration with corporate actors may encourage the demand for nonprofit accountability, and therefore the introduction of business-like instruments and the need of investing in professionals who "can write grant applications and reports that satisfy contractors" [50] (p. 78). Moreover, this situation does not mean that volunteers become less important, but rather that they tend to be managed in a more professional way and coexist with a larger portion of paid employees, generating tensions and conflicts between both groups [10].

These problems are due to the different identities and values that characterize nonprofits (or volunteering) and businesses (or professionalization), because the main focus of the volunteer identity lies in the services, where elements such as creativity, emotional proximity to the target group, and a readiness to help others were emphasized. By contrast, managerial identity is characterized by ideas of professional fundraising, predictability and investment concerning resources, and by structure and distance concerning the organization's service" [10] (p. 651).

It is reasonable to expect that learning about management techniques brings nonprofits closer to the values of the for-profit world, along with the introduction of business tools and the adoption of a 'managerial identity' based on formalization and efficiency. Furthermore, whereas volunteers are more oriented toward mission achievement (because they are committed to the social cause), paid managers and employees will likely focus more their attention and efforts on reducing costs and/or improving revenues (because their jobs and salaries depend on their efficiency). The probable outcome is that nonprofits "may divert their attention away from other stakeholders; in particular, it may decrease the responsiveness to the needs of beneficiaries" [9] (p. 10) and reduce the personnel's identification with the social mission.

Accordingly, two possible negative consequences of professionalization in nonprofits are the existence of goal displacement and the emergence of conflicts between paid and unpaid personnel [11]. Given that "formalization [has] significant negative impacts on volunteer motivation" [10] (p. 654), an emphasis on formalization will lead overall to the loss of personnel identification with (and commitment to) the values and social mission of the organization, with a probable negative effect on mission accomplishment. Thus, we anticipate that:

Hypothesis 4a (H4a). The extent to which a nonprofit develops a process of learning about management techniques as a result of the partnership is positively associated with the degree of formalization in the nonprofit.

Hypothesis $\mathbf{4 b} \mathbf{( H 4 b )}$. The degree of formalization in the nonprofit is positively associated with the level of conflict between paid employees and volunteers.

Hypothesis $\mathbf{4 c} \mathbf{( H 4 c )}$. The level of conflict between paid employees and volunteers is negatively associated with personnel identification with the values and mission of the nonprofit.

However, we can also expect that the learning process will help the nonprofit access information and skills related to current human resource management techniques, oriented to improve the well-being of both types of personnel. These include providing support, training, opportunities for professional development, participation, improved communication and feedback, work-family balance, perceived justice, etc. [51-53]. Such practices involve a systematic effort to obtain information about the personnel's individual needs, to collect information about the obstacles in undertaking 
their tasks and to evaluate their degree of satisfaction. All this information should be used to adjust tasks to the capabilities of personnel, taking into account their professional development, and actively seeking to improve training opportunities and working conditions. In turn, personnel's satisfaction and identification with the values of the organization will be improved.

In the particular case of volunteers, this approach can play a significant role in order to improve their motivation, since their commitment depends on factors such as the existence of associational advantages derived from belonging to a community, the perceived importance of volunteer work and contribution, the volunteers' pride in the organization, the perceived support provided by the organization (training, recognition, etc.), and satisfaction and identification with the nonprofit's values $[11,12,14,54-56]$. Our last hypotheses posit that:

Hypothesis 5a (H5a). The extent to which a nonprofit develops a process of learning about management techniques as a result of the partnership is positively associated with the development of human resource practices focused on improving the well-being of personnel.

Hypothesis $\mathbf{5 b} \mathbf{b} \mathbf{H} \mathbf{5 b})$. The development of human resource practices focused on improving personnel's well-being is positively associated with personnel's identification with the values and mission of the nonprofit.

Overall, the conceptual model of our research is depicted in Figure 1.

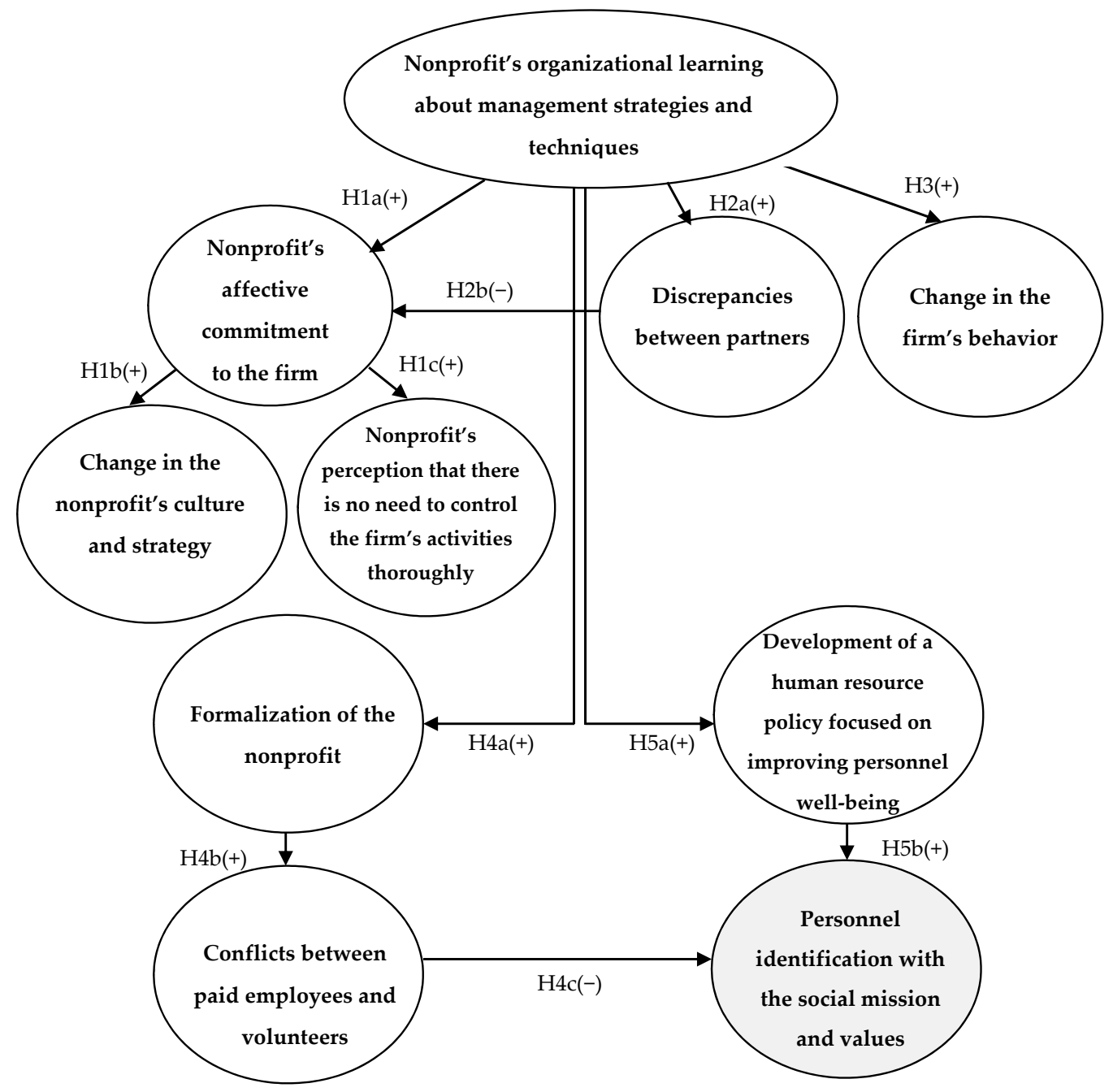

Figure 1. Conceptual Model. 


\subsection{Methodology}

\subsubsection{Data Collection and Sample Description}

To test the research hypotheses, we conducted quantitative-based research and surveyed a representative sample of Spanish foundations, which has also been the origin of other previous works focused on analyzing (1) the effects of value-added partnerships on nonprofits' results [11]; (2) the moderating effect of the type of firm's contribution to the partnership [12], or the nonprofit's kind of funding strategy [14]; and (3) the extent to which the deployment of certain internal capabilities in nonprofits influences different kinds of innovations in these organizations [13].

Foundations are a particular type of nonprofit [57] that demand special research attention due to [11-14]: (1) the growth they have experienced in developed countries, e.g., the European Foundation Centre [58] estimates that there are approximately 110,000 foundations in Europe, whose projects and programs represent between 83 and 150 billion euros annually, and employ up to one million people; (2) their critical role as a funding source within the nonprofit sector [59]; and (3) the growing demands for their accountability, particularly from resource providers such as partners and donors [60].

Following the European Commission and the European Foundation Centre, we conceptualize a foundation as a non-membership based nonprofit. This loose definition reflects not only the diversity of European foundations and their remarkable differences with the US-with many European foundations operating programs rather than giving grants—-but also integrates the distinct features of Spanish foundations.

Most Spanish foundations show low endowments (in 2008 only $6.6 \%$ of foundations had endowments over 2,400,000 Euros). Thus, BNPP tend to play an increasingly relevant role. The fact that Spain presents one of the highest figures of registered public-benefit foundations in the European Union further explains why analyzing Spanish foundations is an interesting study [61].

Because one of the main problems of a survey-based methodology is the so-called common method variance (i.e., variance that is attributable to the measurement method rather than to the constructs the measures represent), with the objective of reducing this potential bias we carried out a two-step survey [62]. In a first step we collected data about: (1) the general description of the partnership (particularly, the nonprofit's affective commitment to the firm, the change in the culture and strategy of the nonprofit as a consequence of the collaboration, the nonprofit's perception about the need to control the activities developed by the firm thoroughly, and the level of discrepancies between the partners); and (2) the nonprofit's main strategies and results (among them, the nonprofit's development of human resource policies oriented to improve personnel well-being, and the perception of the degree of personnel identification with the values and mission of the nonprofit). One year later, detailed information regarding our basic predictor variable, i.e., the degree of organizational learning about management techniques as a consequence of the partnership, was collected, as well as more specific information regarding the consequences of the collaboration in terms of the level of formalization of the nonprofit, the degree of conflicts between paid employees and volunteers, and the nonprofit's perception about the changes in the firm's behavior. With this time lag, we tried to avoid as far as possible direct connections between the measurement of the predictor and the criterion variables.

The first survey was carried out at the end of 2011. The Spanish Institute for Strategic Analysis of Foundations allowed us to get access to the national census of 9050 Spanish foundations existing at that time [61]. We had data about the basic descriptors of each of these foundations, i.e., age, type of administrative registry, founders, geographical scope, model and types of activities, beneficiaries, and size of organizations, so we could randomly select a representative number of foundations in each category to generate a preliminary sample of 525 foundations. We sent an e-mailed questionnaire to the person in charge of daily decision-making in each of these 525 foundations, from whom we obtained 325 valid questionnaires (sample error of $\pm 5.34 \%$ at a $95 \%$ confidence level). Of the 325 respondents, $185(56.92 \%)$ confirmed that their organization had been engaged in a BNPP at some moment of time in the past three years (Table 1 ). 
Table 1. Sample Description.

\begin{tabular}{|c|c|c|c|c|c|}
\hline & scriptors & $\begin{array}{c}\text { Spanish } \\
\text { Foundation Sector } \\
(N=9050)^{1}\end{array}$ & $\begin{array}{c}\text { Sample } \\
\text { (First Step) } \\
(N=325)\end{array}$ & $\begin{array}{l}\text { Partnerships } \\
\text { (First Step) } \\
(N=185)\end{array}$ & $\begin{array}{l}\text { Partnerships } \\
\text { (Second Step) } \\
\quad(N=104)\end{array}$ \\
\hline \multirow{3}{*}{$\begin{array}{l}\text { Year of legal } \\
\text { incorporation }^{2}\end{array}$} & Until 1994 & $34.70 \%$ & $31.60 \%$ & $27.00 \%$ & $25.90 \%$ \\
\hline & Between 1995 and 2002 & 31.5 & 34.8 & 37.8 & 42.3 \\
\hline & After 2002 & 33.8 & 33.5 & 35.1 & 31.7 \\
\hline \multirow{2}{*}{ Type of registry } & National registry & 29.2 & 32.9 & 36.8 & 32.7 \\
\hline & Autonomic registry & 70.8 & 67.1 & 63.2 & 67.3 \\
\hline Public initiative & Yes & 9.2 & 12.6 & 15.1 & 12.5 \\
\hline \multirow{3}{*}{ Founders } & Natural persons & 52.6 & 45.9 & 45.4 & 49.5 \\
\hline & Public legal persons & 31.3 & 31.3 & 31.6 & 29 \\
\hline & Private legal persons & 55.3 & 55.3 & 58.2 & 59 \\
\hline \multirow{4}{*}{$\begin{array}{l}\text { Geographic scope } \\
\text { of activities }\end{array}$} & Local-provincial & 28.3 & 24.9 & 17.9 & 23.1 \\
\hline & Autonomic & 34.7 & 35.4 & 37.8 & 36.5 \\
\hline & National & 23.3 & 24.9 & 25.9 & 23.1 \\
\hline & International & 13.6 & 14.8 & 18.4 & 17.3 \\
\hline \multirow{10}{*}{$\begin{array}{l}\text { ICNPO Groups } \\
\text { (International } \\
\text { Classification of } \\
\text { Nonprofit } \\
\text { Organizations) }\end{array}$} & Culture/recreation & 46.5 & 42.9 & 44.9 & 43.3 \\
\hline & Education and research & 52 & 54.9 & 56.8 & 49 \\
\hline & Health & 21 & 24.7 & 23.2 & 21.2 \\
\hline & Social services & 35.3 & 36.1 & 33.5 & 41.3 \\
\hline & Environment & 13.5 & 12.7 & 13.5 & 18.3 \\
\hline & Development and housing & 27.7 & 31.8 & 35.1 & 33.7 \\
\hline & Law, advocacy and polities & 6.2 & 8 & 9.2 & 12.5 \\
\hline & International & 12.7 & 18.2 & 21.1 & 23.1 \\
\hline & Religion & 3.7 & 2.8 & 1.1 & 1 \\
\hline & $\begin{array}{c}\text { Business/professional } \\
\text { associations, unions }\end{array}$ & 1.6 & 3.4 & 5.4 & 5.8 \\
\hline \multirow{4}{*}{ Model of activity } & Grant making & 31.9 & 33.1 & 28.8 & 30.8 \\
\hline & $\begin{array}{l}\text { Operating their own } \\
\text { programs/projects }\end{array}$ & 74.6 & 78.6 & 84.8 & 86.5 \\
\hline & Social mobilization & 18.6 & 18 & 20.7 & 22.1 \\
\hline & $\begin{array}{l}\text { Operating their own } \\
\text { establishments }\end{array}$ & 15.3 & 18.6 & 17.4 & 19.2 \\
\hline \multirow{2}{*}{ Beneficiaries } & Legal persons & 54.2 & 57.4 & 62.7 & 62.5 \\
\hline & Natural persons & 96 & 96.6 & 96.8 & 96.2 \\
\hline \multirow[b]{2}{*}{ Size } & Revenue $<2,400,000 €$ & 88.4 & 83.1 & 79 & 78.3 \\
\hline & Revenue $>2,400,000 €$ & 11.6 & 16.9 & 21 & 21.7 \\
\hline
\end{tabular}

${ }^{1}$ Sources: Foundation registries and other public sources; ${ }^{2}$ These thresholds correspond to the first Spanish Foundation Law of 1994 and the current Spanish Foundation Law of 2002 (Law 50/2002 of 26th December, on Foundations).

The potential existence of a nonresponse bias $[63,64]$ was assessed by comparing (1) the profile of the final sample of 325 foundations with the general descriptors of the sector; and (2) early versus late respondents. In both cases, no statistically significant differences exist.

One year later, we sent a second questionnaire to the same 185 foundations, asking them about 15 issues related to the organizational learning process resulting from the partnership, and the remaining constructs of the model. We obtained the collaboration of 104 foundations in this second round of the research (see Table 1).

\subsubsection{Measures}

Seven-point Likert-type scales were used to measure the variables (see Appendix A), and reflective indicators were employed in the case of multi-item scales.

Our measure of organizational learning (OL) involves the basic three processes usually employed to describe this construct: information acquisition (IACQ), dissemination (IDIS), and integration (IINT). They are based on organization learning literature $[31,32,65,66]$.

The scales to assess the nonprofit's affective commitment to the firm (AFC), the level of disagreements and conflicts between the partners (DISCR), and the degree of personnel's identification with the social mission and ethical values of the nonprofit (IDENT) are derived from relationship marketing literature and research on BNPP $[46,67,68]$. As a proxy of the extent to which the nonprofit develops human resource policies focused on improving personnel's well-being, we use the three basic dimensions of the 'internal market orientation' (IMO) approach provided by Gounaris [69]: 
internal market intelligence generation (e.g., collecting information about specific segments of personnel), internal intelligence dissemination (communication between supervisors and personnel), and responses to internal intelligence (e.g., designing tasks, training programs, motivational systems, etc. that meet personnel's needs). Four items serve to evaluate the nonprofit's perception about the change in the firm's behavior resulting from the collaboration with the nonprofit (CHANGE), based on the latest development of the CSR concept [20].

Finally, we employ one single item to measure each of the remaining variables: the change in the nonprofit's culture and strategy (CULTURE), the perception about the need to control the firm's activities thoroughly (CONTROL), formalization (FORMAL), and the level of conflicts between employees and volunteers (CONFL).

\subsubsection{Scale Reliability and Validity}

The results of a confirmatory factor analysis proved the existence of reliable and valid scales. Table 2 shows that the composite reliability coefficients surpass the recommended value of 0.7 in all cases. For its part, not only the standardized lambda parameters are significant and greater than 0.5 , but the average variance extracted (AVE) coefficients are also greater than the recommended value of 0.5 , therefore supporting convergent validity. As two of our variables, i.e., 'organizational learning' and 'internal market orientation', are multidimensional constructs, given that their respective dimensions exhibit convergent validity, we calculated the mean values of each of these dimensions to obtain a three-item factor (OL) for organization learning and another three-item factor (IMO) for internal market orientation. Finally, the fact that the AVE of each construct always surpasses the shared variance between each pair of constructs supports the presence of discriminant validity (Table 3).

Table 2. Reliability and Validity of the Scales.

\begin{tabular}{|c|c|c|c|c|}
\hline Factor & Item & Factor Loadings & Composite Reliability Coefficient & AVE \\
\hline $\begin{array}{c}\text { Affective } \\
\text { commitment (AFC) }\end{array}$ & $\begin{array}{l}\text { AFC1 } \\
\text { AFC2 } \\
\text { AFC3 }\end{array}$ & $\begin{array}{l}0.618^{* * *} \\
0.886 \text { *** } \\
0.810^{* * *}\end{array}$ & 0.82 & 0.608 \\
\hline $\begin{array}{c}\text { Internal market } \\
\text { orientation (IMO) }\end{array}$ & $\begin{array}{c}\text { IIG } \\
\text { IID } \\
\text { RESP }\end{array}$ & $\begin{array}{l}0.829 * * * \\
0.787 * * * \\
0.779 * * *\end{array}$ & 0.841 & 0.638 \\
\hline $\begin{array}{l}\text { Changes in the firm's } \\
\text { behavior (CHANGE) }\end{array}$ & $\begin{array}{l}\text { CHANGE1 } \\
\text { CHANGE2 } \\
\text { CHANGE3 } \\
\text { CHANGE4 }\end{array}$ & $\begin{array}{l}0.883^{* * *} \\
0.798^{* * * *} \\
0.647^{* * * *} \\
0.607^{* * *}\end{array}$ & 0.827 & 0.551 \\
\hline
\end{tabular}

Goodness-of-fit measures

Satorra-Bentler $\chi 2=222.5053(p=0.00762)$; Satorra-Bentler $\chi 2$ /degrees of freedom $=1.28$; Bentler-Bonett Non Normed Fit Index $=0.910$; Comparative Fit Index $=0.925$; Root Mean Square Error of Approximation $=0.057$ 
Table 3. Discriminant Validity.

\begin{tabular}{ccccccc}
\hline & OL & AFC & DISCR & IMO & IDENT & CHANGE \\
\hline OL & $\mathbf{0 . 8 3 8}$ & & & & & \\
AFC & $0.269^{* *}$ & $\mathbf{0 . 7 8 0}$ & & & & \\
DISCR & $0.236^{* *}$ & -0.033 & $\mathbf{0 . 7 6 9}$ & & & \\
IMO & $0.249^{* *}$ & $0.165^{*}$ & -0.064 & $\mathbf{0 . 7 9 9}$ & & \\
IDENT & $0.196^{*}$ & $0.108^{* * *}$ & 0.068 & $0.654^{* * *}$ & $\mathbf{0 . 8 4 3}$ & \\
CHANGE & $0.593^{* *}$ & $0.238^{* * *}$ & 0.133 & $0.315^{* * *}$ & 0.053 & $\mathbf{0 . 7 4 2}$ \\
\hline
\end{tabular}

Notes: The values on the diagonal are the square roots of the AVE coefficients of each of the 6 constructs. The values off the diagonal are the correlations between each pair of constructs. ${ }^{* * *} p<0.01 .{ }^{* *} p<0.05 .{ }^{*} p<0.1$.

\subsubsection{Model Estimation}

We employed Structural Equation Modelling with EQS 6.2 for Windows to test the research hypotheses. This multivariate method is suitable because some of our constructs are latent variables which are not directly observed. Furthermore, the same variable may represent a predictor (independent variable) in one equation and a criterion (dependent variable) in another equation. The goodness-of-fit measures are appropriate.

\section{Results}

In Table 4, we provide the results of the estimation. Results provide support for $\mathrm{H} 1 \mathrm{a}, \mathrm{H} 1 \mathrm{~b}$, and H1c. Organizational learning about management techniques is directly and positively associated with the development of affective commitment to the firm $(p<0.05)$, which in turn is positively linked to the change in the nonprofit's culture and strategy $(p<0.05)$ and the nonprofit's belief that there is no need to control the firm's activities thoroughly $(p<0.01)$. But the results also show that organizational learning fosters the existence of discrepancies between the partners related to decisions and strategies $(p<0.05)$, as well as a change in the firm's behavior resulting from the collaboration $(p<0.01)$, as $\mathrm{H} 2 \mathrm{a}$ and $\mathrm{H} 3$ expected, respectively. However, $\mathrm{H} 2 \mathrm{~b}$ is not supported (although the coefficient presents the expected negative sign).

Table 4. The Effects of Nonprofit's Organizational Learning about Management Techniques.

\begin{tabular}{cccc}
\hline Causal Relationships & Standardized Coefficients & Causal Relationships & Standardized Coefficients \\
\hline H1a: $\mathrm{OL} \rightarrow$ AFC & $0.334^{* *}$ & H4a: OL $\rightarrow$ FORMAL & $0.624^{* * *}$ \\
H1b: AFC $\rightarrow$ CULTURE & $0.200^{* *}$ & H4b: FORMAL $\rightarrow$ CONFL & $0.471^{* *}$ \\
H1c: AFC $\rightarrow$ CONTROL & $0.330^{* * *}$ & H4c: CONFL $\rightarrow$ IDENT & $-0.114^{*}$ \\
H2a: OL $\rightarrow$ DISCR & $0.244^{* *}$ & H5a: OL $\rightarrow$ IMO & $0.294^{* *}$ \\
H2b: DISCR $\rightarrow$ AFC & -0.098 & H5b: IMO $\rightarrow$ IDENT & $0.671^{* * *}$ \\
H3: OL $\rightarrow$ CHANGE & $0.640^{* * *}$ & - & - \\
\hline \multicolumn{2}{c}{ Goodness-of-fit measures }
\end{tabular}

Satorra-Bentler $\chi 2=331.2615(p=0.00507)$; Satorra-Bentler $\chi 2$ /degrees of freedom $=1.24$; Bentler-Bonett Non Normed Fit Index $=0.902$; Comparative Fit Index $=0.912$; Root Mean Square Error of Approximation $=0.052$

${ }^{* * *} p<0.01 ;{ }^{* *} p<0.05 ;{ }^{*} p<0.1$.

Organizational learning about management techniques positively boosts formalization, as $\mathrm{H} 4 \mathrm{a}$ expected $(p<0.01)$, and formalization leads to increased conflicts between paid employees and volunteers, supporting $\mathrm{H} 4 \mathrm{~b}(p<0.05)$. For its part, the existence of these conflicts lowers the overall personnel identification with the social mission, in line with $\mathrm{H} 4 \mathrm{c}$ (in this case $p<0.10$ ). Finally, both H5a $(p<0.05)$ and $\mathrm{H} 5 \mathrm{~b}(p<0.01)$ show the expected results: organizational learning fosters the development of a human resource management style focused on personnel well-being, and this type of approach improves personnel identification with the social mission of the nonprofit. 


\section{Discussion and Conclusions}

Partnerships between businesses and nonprofits have been the focus of an intense debate from an ethical perspective, given the different potential consequences derived from a close interaction between two actors with inherently diverse identities, goals, and responsibilities. Particularly, previous studies have warned about the risks for nonprofits of co-optation and loss of personnel identification with the social mission, which give rise to a possible loss of the essence and the independence of nonprofits (by weakening their role as advocates or watchdogs and constraining them to service provision). However, it is not unreasonable to think that these potential risks could vary depending on the type of value generated by the partnership. Based on the consequentialist approach as the basic ethical framework (i.e., an approach that considers that decisions generate different consequences, the correct moral conduct being that action that achieves the most good as a whole), we have examined the extent to which empowering the nonprofit by means of a learning process about management methods influences these kinds of risks. Our results show the existence of both positive and negative effects.

Regarding co-optation, we can explain the appearance of this mixed impact if we consider, on the one hand, that organizational learning occurs as a result of a close relationship between the partners, in which personal ties and trust represent a critical underlying factor. This situation will likely encourage the nonprofit's identification with the firm and the risk of co-optation, consistent with the reasoning provided by Baur and Schmitz [9]. On the other hand, the results of this learning process provide nonprofits with resources and capabilities about management instruments so that they can be in a better position to proactively detect, shape, and seize opportunities and threats, and make decisions accordingly. This type of skill reinforces the independence and power position of the nonprofit and, therefore, its capability to question the firm's behavior and decisions, as well as its capacity to change them.

Similarly, and with regard to the potential loss of personnel identification with the nonprofit's social mission, professionalization in nonprofits due to the existence of managerial learning generates two opposite influences. On the one hand, as Kreutzer and Jäger [10] posit, professionalization is associated with improved formalization of the nonprofit, which in turn leads to conflicts between paid employees and volunteers and hinders overall personnel involvement with the social mission. On the other hand, however, professionalization also helps nonprofits learn about human resource management techniques oriented to improve the well-being of both types of personnel, thus enhancing its commitment and satisfaction.

These results provide several contributions for both academics and practitioners. Firstly, the analysis of the consequences of the partnership from the viewpoint of the nonprofit is one of the main contributions of our study, because it is precisely in the non-profit sector where the controversy about the desirability of partnering with firms is more intense [9,70,71], and whereas firms appear to exhibit a more positive attitude toward partnerships, nonprofits tend to be more vigilant, or even show a clear hostility to collaborating with businesses [6,72]. However, the insights derived from our results show that not all types of BNPP involve the same degree of ethical risks for nonprofits, because high-value partnerships generate outcomes that can reduce the potential risks of co-optation and loss of personnel identification with the social mission.

Secondly, we reveal some clues for businesses to extend their philanthropic efforts beyond those types of collaborations that mainly generate resource dependency for nonprofits. As resource dependency represents one of the main factors that lead to goal displacement in nonprofits, the identification of mechanisms that reduce power asymmetries can improve the sustainability and social impact of the partnership. In particular, empowering nonprofits by enhancing their management capabilities might counteract the negative impacts associated with the existence of a situation of power imbalance and resource dependency, fostering the alliance effectiveness and sustainability. Similar to BNPP, professionalization represents another focus of controversy in the nonprofit sector [10], but according to our results the development of professional competences can lead to social benefits (for example, in terms of the nonprofits' capability to change the firm's behavior, its capability to 
assess the firm's decisions and strategies in a more technical and professional way, or the development of human resource policies aimed at improving personnel's well-being). This result has important implications regarding the type of contribution that the firm should bring to the partnership if its social outcomes are to be enhanced.

Thus, although cash is the usual (and many times, the predominant) type of contribution provided by firms, in addition to cash the alliance should involve other types of resources and activities to foster directly or indirectly, through improved management effectiveness and the benchmarking exercise, nonprofit performance [73] and, ultimately, a greater social impact. The current study corroborates the relevance that organizational learning about management techniques has in the nonprofit sector, and highlights the role played by partnering with other organizations, particularly with firms, in order to develop it. Prior research on organizational learning has generally analyzed large for-profit organizations, with little attention paid to nonprofits (with some exceptions such as Prugsamatz [41], or Weerawardena and Sullivan Mort [74], which have not analyzed the influence of BNPP). However, the new competitive environment is forcing nonprofits to change their behavior and to foster organizational learning [41].

Consequently, firms and nonprofits should develop organizational settings that encourage higher-order learning through a 'participative infrastructure', i.e., "an appropriate and supporting culture that provides systems and procedures to facilitate information flows, advances appropriate employee development, and encourages risk-taking, experimentation and a genuine entrepreneurial orientation" [75] (p. 152). Such a supporting culture, according to Nonaka [40], is characterized by promoting individual autonomy, commitment to the creation and adoption of new knowledge, fluctuation and creative chaos, diversity of thinking, and open dialogue. Precisely, an absolutely necessary mechanism for this 'participative infrastructure' is the existence of an effective communication strategy, in order to face the tensions usually associated with cross-sector partnerships, in which the potential for ethical conflicts is greater than in intra-sector alliances, as partners come from different sectors, sometimes with antagonistic origins, visions, missions, values, motivations, capabilities, and organizational characteristics [76].

From a practical point of view, the first step for really valuing the partner's full potential contribution and overcoming misunderstandings ex ante consists of devoting effort to sharing a common language and then avoiding problematic words (e.g., business plan, profit, etc.); using instead other more neutral alternatives (e.g., action plan, added value, etc.). Furthermore, both business and nonprofit managers should foster the climate of trust, by means of activities that develop a mutual understanding (e.g., training and seminar sessions, promoting physical proximity of team members, encouraging temporary personnel mobility among groups to enhance integration of different perspectives, and so on). Personal contacts and appropriate reporting procedures are essential, as well as a clear internal and external communication plan with the aim of encouraging the institutionalization of the partnership. Both internal and external stakeholders should become aware of how the partnership can benefit and contribute to achieve their own objectives.

Nevertheless, in the case of BNPP the use of mechanisms to enhance trust has to be combined with other types of actions oriented to reduce the ethical hazards associated with these collaborations, reinforcing the political conception of CSR proposed by Baur and Schmitz [9]. Among other types of strategies, it is important that in order to strengthen this conception, the firm adopts a long-term vision focused on the so-called 'social innovation', understood as "new ideas (products, services and models) that simultaneously meet social needs and create new social relationships or collaborations" [23] (p. 3). Social innovation practices share two basic characteristics [22,23,77]. Firstly, and from a normative standpoint, they are oriented towards the common good, and attempt to address global challenges such as unemployment, erosion of the social security system, climate change, poverty, ageing, etc. Secondly, they involve new forms of collaboration among the for-profit sector, governments, nonprofit organizations, citizens, employees, social networks, and beneficiaries or customers. 
In line with the conceptualization of social innovation around these two main characteristics, firms should encourage a dual CSR strategy. The first one "is interested in solutions to major social problems, based on entrepreneurial initiatives that place emphasis on philanthropy, individual responsibility, and on the market more than on the State" [78] (p. 49). The second approach "puts greater emphasis on the collective nature of the processes and products of social innovation. It sees innovations as steps leading to social change, namely, the transformation of social relations that are at the origin of social problems" [78] (p. 49). It focuses on fostering the participation of various societal actors (the "users") in cooperative actions aimed at implementing new values, rules, and norms regarding the workplace, life conditions, community development and so on.

Partnering between corporations and nonprofits can contribute to both dimensions of social innovation by means of the development and implementation of increasingly sophisticated collaborations "with a problem-solving focus, including joint product development, pooled financing structures, voluntary standard creation, and asset sharing" [79] (p. 26). Examples include the co-development of specific projects between the firm and the nonprofit to design and provide new products and/or services aimed at solving social or environmental problems, or co-joint projects to advocate for regulation and policy change around shared interests.

It is noteworthy that to achieve this type of high value-added partnership, top management commitment, and specifically its attitude toward risk, will be critical, since developing this approach will probably involve a change in the culture, ethical values, and motivation of the corporation. For instance, the change towards a political conception of CSR (or a social innovation-based culture) will likely involve: (1) a change in the global orientation of the organization (the set of ethical values that guide the firm's activities, how the firm identifies the challenges it attempts to face, how it defines its target groups and fields of activity); (2) a change in the way by which the members of this organization participate in decision processes (fostering an open and participatory organizational culture); (3) a change in its degree of external openness toward external stakeholders (encouraging the external stakeholders' feedback, involvement and active participation in policy making); and (4) a change in the extent to which it develops an advocacy work aimed at sensitizing policy makers.

Several topics are interesting for further research. One possibility is analyzing the effect of moderating variables that could influence the intensity of the effects, for example the degree of power asymmetry in the relationship. Another possibility consists of analyzing sustainable innovation as a result of BNPP, an under-researched topic. Only a few theoretical or mainly case-study based works have specifically examined this issue [16,80-83].

Regarding the connection between social innovation and performance, the identification of the potential negative consequences of social innovation resulting from BNPP emerges as a relevant research topic from the ethical and sustainability perspective: is social innovation always morally right per se? Are the consequences derived from a particular innovation more favorable than unfavorable for all relevant stakeholders? Do some of these activities present different or even opposite consequences in the short and in the long term?

Acknowledgments: The authors acknowledge funding provided by the Spanish Ministry of Economy and Competitiveness, as part of its R\&D Plan (2009-2011), for the project entitled "Foundations as a key factor of Spanish firms' corporate social responsibility strategy. Bi-directional analysis of the foundation-firm relationship following a marketing approach" (MICINN-09-ECO2009-11377). The authors also acknowledge the Spanish Association of Foundations (AEF) for endorsing that research project.

Author Contributions: María José Sanzo, Luis I. Álvarez, and Marta Rey conceived and designed the research project; María José Sanzo, Luis I. Álvarez, and Marta Rey provided bibliographic material; Luis I. Álvarez and Marta Rey carried out the survey and collected the data; María José Sanzo analyzed the data; María José Sanzo, Luis I. Álvarez, and Marta Rey discussed the implications of the research; María José Sanzo wrote the paper.

Conflicts of Interest: The authors declare no conflict of interest. The founding sponsors had no role in the design of the study; in the collection, analyses, or interpretation of data; in the writing of the manuscript, and in the decision to publish the results. 


\section{Appendix A}

Table A1. Scale of Organizational Learning (Seven-Point Likert Scale).

\begin{tabular}{|c|c|c|c|}
\hline \multicolumn{4}{|c|}{$\begin{array}{l}\text { Nonprofit Organizational Learning (OL) } \\
\text { The nonprofits were asked to indicate their degree of agreement with the following sentences }\end{array}$} \\
\hline \multicolumn{2}{|c|}{$\begin{array}{l}\text { Information Acquisition (IACQ) } \\
\text { The business-nonprofit partnership has allowed our organization to obtain information about ... }\end{array}$} & \multirow{2}{*}{$\begin{array}{c}\text { Mean } \\
2.60\end{array}$} & \multirow{2}{*}{$\begin{array}{l}\text { S.D. } \\
1.67\end{array}$} \\
\hline IACQ1 & Organizational strategies and techniques & & \\
\hline IACQ2 & Marketing/communication/public relations management & 2.84 & 1.85 \\
\hline IACQ3 & Human resource management & 2.37 & 1.55 \\
\hline IACQ4 & Financial management & 2.54 & 1.76 \\
\hline IACQ5 & Information and communication technologies & 2.86 & 1.94 \\
\hline IACQ6 & Potential beneficiaries, donors and/or other key stakeholders & 3.21 & 1.97 \\
\hline IACQ7 & New trends on social innovation & 2.81 & 1.76 \\
\hline IACQ8 & Quality assurance systems & 2.14 & 1.48 \\
\hline IACQ9 & Performance metrics & 2.44 & 1.73 \\
\hline \multicolumn{2}{|c|}{ Information Dissemination (IDIS) } & Mean & S.D. \\
\hline IDIS1 & $\begin{array}{l}\text { The information that we have acquired from the firm has been disseminated throughout } \\
\text { the entire organization }\end{array}$ & 4.46 & 2.11 \\
\hline IDIS2 & $\begin{array}{l}\text { We consider that the knowledge that we have obtained from the firm is part of our } \\
\text { organization }\end{array}$ & 4.35 & 2.07 \\
\hline \multicolumn{2}{|c|}{ Information Integration (IINT) } & Mean & S.D. \\
\hline IINT1 & Our organization has applied this information in its activities and routines & 4.01 & 1.91 \\
\hline IINT2 & The partnership has allowed us to improve our services & 4.37 & 1.85 \\
\hline IINT3 & The partnership has allowed our organization to be more efficient & 3.99 & 1.94 \\
\hline IINT4 & Our organization has introduced changes in its management as a result of the partnership & 2.87 & 1.90 \\
\hline
\end{tabular}

Table A2. Scale of Affective Commitment (Seven-Point Likert Scale).

\begin{tabular}{llcc}
\hline Nonprofit Affective Commitment to the Firm (AFC) & Mean & S.D. \\
\hline AFC1 & We have a strong sense of loyalty toward this firm & 5.40 & 1.76 \\
\hline AFC2 & $\begin{array}{l}\text { We want to remain a partner of this firm's because we genuinely enjoy our relationship } \\
\text { with them }\end{array}$ & 5.99 & 1.53 \\
\hline AFC3 & $\begin{array}{l}\text { We are willing to make long-term investments in this relationship because it is a pleasure } \\
\text { working with them }\end{array}$ & 5.56 & 1.73 \\
\hline
\end{tabular}

Table A3. Scale of Change in the Nonprofit's Culture and Strategy (Seven-Point Likert Scale).

\begin{tabular}{llcc}
\hline Change in the Nonprofit's Culture and Strategy (CULTURE) & Mean & S.D. \\
\hline CULTURE & $\begin{array}{l}\text { The development of the partnership involved a change in the culture and } \\
\text { strategy of our organization }\end{array}$ & 1.85 & 1.40 \\
\hline
\end{tabular}

Table A4. Scale of Nonprofit's Perception that There Is No Need to Control the Firm's Activities Thoroughly (Seven-Point Likert Scale).

\begin{tabular}{lcc}
\hline $\begin{array}{l}\text { Nonprofit's Perception that there is no Need to Control the Firm's Activities } \\
\text { Thoroughly (CONTROL) }\end{array}$ & Mean & S.D. \\
\hline CONTROL $\quad$ Activities with this firm do not have to be closely supervised & 4.83 & 1.85 \\
\hline
\end{tabular}

Table A5. Scale of Conflict between the Partners (Seven-Point Likert Scale).

\begin{tabular}{llc}
\hline Discrepancies and Conflicts between the Partners Related to Decisions and Strategies (DISCR) & Mean & S.D. \\
\hline DISCR1 & $\begin{array}{l}\text { The working relationship with this firm has passed through some unstable, } \\
\text { conflictive stages }\end{array}$ & 2.18 \\
\hline DISCR2 & A large number of conflicts-latent or manifest-exist between our organizations & 1.69 \\
\hline DISCR3 & $\begin{array}{l}\text { The firm and our organization have frequent, substantial discrepancies concerning } \\
\text { important matters }\end{array}$ & 1.24 \\
\hline DISCR4 & When conflictive situations arise, the firm does nothing to find a solution & 1.77 \\
\hline
\end{tabular}


Table A6. Scale of Change in the Firm's Behavior (Seven-Point Likert Scale).

\begin{tabular}{llcc}
\hline Change in the Firm's Behavior Resulting from the Collaboration (CHANGE) & Mean & S.D. \\
\hline CHANGE1 & The firm has changed its objectives, integrating the values of our nonprofit & 2.66 & 2.14 \\
\hline CHANGE2 & The firm has changed its internal processes following sustainability criteria & 2.03 & 1.93 \\
\hline CHANGE3 & $\begin{array}{l}\text { The firm has developed a new business model not only with the aim of obtaining } \\
\text { profits, but also with the objective of satisfying a social need }\end{array}$ & 2.44 & 2.13 \\
\hline CHANGE4 & The firm has developed new products that incorporate the values of our nonprofit & 2.73 & 2.25 \\
\hline
\end{tabular}

Table A7. Scale of Formalization (Seven-Point Likert Scale).

\begin{tabular}{llcc}
\hline Improved Formalization of the Nonprofit (FORMAL) & Mean & S.D. \\
\hline FORMAL & $\begin{array}{l}\text { The formalization and bureaucratization of our nonprofit has been } \\
\text { increased as the result of the partnership }\end{array}$ & 2.28 & 1.62 \\
\hline
\end{tabular}

Table A8. Scale of Conflicts between Paid Employees and Volunteers (Seven-Point Likert Scale).

\begin{tabular}{lccc}
\hline \multicolumn{2}{l}{ Conflicts between Paid Employees and Volunteers (CONFL) } & Mean & S.D. \\
\hline CONFL & The partnership has led to conflicts between paid employees and volunteers & 1.39 & 1.01 \\
\hline
\end{tabular}

Table A9. Scale of Internal Market Orientation (Seven-Point Likert Scale).

\begin{tabular}{llcc}
\hline $\begin{array}{l}\text { Development of a Human Resource Policy Focused on Improving Personnel Well-Being (Internal } \\
\text { Market Orientation) (IMO) }\end{array}$ & Mean & S.D. \\
\hline Internal Market Intelligence Generation (IIG) & 5.68 & 1.27 \\
\hline IIG1 & $\begin{array}{l}\text { The nonprofit emphasizes understanding personnel's (employees' and } \\
\text { volunteers') needs and expectations }\end{array}$ & 4.84 & 1.57 \\
\hline IIG2 & The nonprofit regularly assesses personnel's job satisfaction & 3.76 & 1.86 \\
\hline IIG3 & The organization knows other nonprofits' human resource policies & 5.04 & 1.73 \\
\hline IIG4 & The nonprofit knows the labor market situation within its sector of activity & Mean & S.D. \\
\hline Internal Market Intelligence Dissemination (IID) & 5.53 & 1.40 \\
\hline IID1 & $\begin{array}{l}\text { Personnel report about their private problems when they affect their } \\
\text { performance }\end{array}$ & 5.61 & 1.28 \\
\hline IID2 & $\begin{array}{l}\text { Top management regularly collects information about personnel's } \\
\text { (employees' and/or volunteers') private problems in performing their tasks }\end{array}$ & Mean & S.D. \\
\hline Responses to Internal Intelligence (RESP) & $\begin{array}{l}\text { The jobs are appropriate to the professional capabilities of employees and } \\
\text { volunteers }\end{array}$ & 5.79 & 1.17 \\
\hline RESP1 & $\begin{array}{l}\text { The nonprofit's human resource policy takes into account the personnel's } \\
\text { professional development }\end{array}$ & 5.45 & 1.33 \\
\hline RESP2 & $\begin{array}{l}\text { The nonprofit's human resource policy actively seeks to improve working } \\
\text { conditions. }\end{array}$ & 5.43 & 1.37 \\
\hline RESP3 & $\begin{array}{l}\text { The nonprofit has a personnel training program } \\
\text { RESP4 }\end{array}$ & 4.64 & 2.03 \\
\hline
\end{tabular}

Note: Items in italics were eliminated during the scale validation process.

Table A10. Scale of Personnel Identification with the Social Mission (Seven-Point Likert Scale).

\begin{tabular}{llcc}
\hline \multicolumn{2}{l}{ Personnel Identification with the Social Mission (IDENT) } & Mean & S.D. \\
\hline IDENT1 & Personnel commitment to the nonprofit & 5.88 & 1.11 \\
IDENT2 & Personnel identification with the values of the nonprofit & 5.82 & 1.06 \\
IDENT3 & Personnel satisfaction & 5.61 & 1.04 \\
IDENT4 & Personnel retention rate & 6.06 & 1.18 \\
\hline
\end{tabular}




\section{References}

1. Almog-Bar, M.; Young, D.R. Special issue of Nonprofit Policy Forum on "Policy towards nonprofits in international perspective: Current trends and their implications for theory and practice". Nonprofit Policy Forum 2016, 7, 85-93. [CrossRef]

2. Austin, J.E.; Seitanidi, M.M. Collaborative value creation: A review of partnering between nonprofits and businesses: Part I. Value creation spectrum and collaboration stages. Nonprofit Volunt. Sect. Q. 2012, 41, 726-758. [CrossRef]

3. Austin, J.E.; Seitanidi, M.M. Collaborative value creation: A review of partnering between nonprofits and businesses. Part 2: Partnership processes and outcomes. Nonprofit Volunt. Sect. Q. 2012, 41, 929-968. [CrossRef]

4. Clarke, A.; MacDonald, A. Outcomes to partners in multi-stakeholder cross-sector partnerships. A resource-based view. Bus. Soc. 2016. [CrossRef]

5. Lefroy, K.; Tsarenko, Y. Dependence and effectiveness in the nonprofit-corporate alliance: The mediating effect of objectives achievement. J. Bus. Res. 2014, 67, 1959-1966. [CrossRef]

6. Selsky, J.W.; Parker, B. Cross-sector partnerships to address social issues: Challenges to theory and practice. J. Manag. 2005, 31, 849-873. [CrossRef]

7. Shumate, M.; Hsieh, Y.P.; O'Connor, A. A nonprofit perspective on business-nonprofit partnerships. Bus. Soc. 2016. [CrossRef]

8. Wadham, H.; Warren, R. Inspiring action, building understanding: How cross-sector partnership engages business in addressing global challenges. Bus. Ethics 2013, 22, 47-63. [CrossRef]

9. Baur, D.; Schmitz, H.P. Corporations and NGOs: When accountability leads to co-optation. J. Bus. Ethics 2012, 106, 9-21. [CrossRef]

10. Kreutzer, K.; Jäger, U. Volunteering versus managerialism: Conflict over organizational identity in voluntary associations. Nonprofit Volunt. Sect. Q. 2011, 40, 634-661. [CrossRef]

11. Sanzo, M.J.; Álvarez, L.I.; Rey, M.; García, N. Business-nonprofit partnerships: Do their effects extend beyond the charitable donor-recipient model? Nonprofit Volunt. Sect. Q. 2015, 44, 379-400. [CrossRef]

12. Sanzo, M.J.; Álvarez, L.I.; Rey, M.; García, N. Business-nonprofit partnerships: A new form of collaboration in a corporate responsibility and social innovation context. Serv. Bus. 2015, 9, 611-636. [CrossRef]

13. Sanzo, M.J.; Álvarez, L.I.; Rey, M. How to encourage social innovations: A resource-based approach. Serv. Ind. J. 2015, 35, 430-447. [CrossRef]

14. Álvarez, L.I.; García, N.; Rey, M.; Sanzo, M.J. Business-nonprofit partnerships as a driver of internal marketing in nonprofit organizations. Consequences for nonprofit performance and moderators. BRQ-Bus. Res. $Q$. 2017, 20, 112-123. [CrossRef]

15. Barroso-Méndez, M.J. Procesos de Asociación Entre Empresas y ONGD. Un Modelo de Éxito Desde la Perspectiva del Marketing de Relaciones. Ph.D. Thesis, Universidad de Extremadura, Badajoz, Spain, 29 October 2015.

16. Jamali, D.; Yanni, M.; Abdallah, H. Strategic partnerships, social capital and innovation: Accounting for social alliance innovation. Bus. Ethics 2011, 20,375-391. [CrossRef]

17. Kolk, A.; van Tulder, R.; Kostwinder, E. Business and partnerships for development. Eur. Manag. J. 2008, 26, 262-273. [CrossRef]

18. Rondinelli, D.A.; London, T. How corporations and environmental groups cooperate: Assessing cross-sector alliances and collaborations. Acad. Manag. Perspect. 2003, 17, 61-76. [CrossRef]

19. Valor, C.; Merino, A. Relationship of business and NGOs: An empirical analysis of strategies and mediators of their private relationship. Bus. Ethics 2009, 18, 110-126. [CrossRef]

20. Halme, M.; Laurila, J. Philanthropy, integration or innovation? Exploring the financial and societal outcomes of different types of corporate responsibility. J. Bus. Ethics 2009, 84, 325-339. [CrossRef]

21. Howaldt, J.; Schwarz, M. Social Innovation: Concepts, Research Fields and International Trends; IMA/ZLW: Aachen, Germany, 2010.

22. Moulaert, F.; Martinelli, F.; Swyngedouw, E.; Gonzalez, S. Towards alternative model(s) of local innovation. Urban Stud. 2005, 42, 1669-1990. [CrossRef]

23. Murray, R.; Caulier-Grice, J.; Mulgan, G. The Open Book of Social Innovation; The Young Foundation/NESTA (National Endowment for Science, Technology and the Arts): London, UK, 2010. 
24. World Bank. What Is Empowerment? Available online: http://web.worldbank.org/WBSITE/ EXTERNAL/TOPICS / EXTPOVERTY / EXTEMPOWERMENT/0,,contentMDK:20272299 pagePK: 210058 piPK:210062 theSitePK:486411,00.html (accessed on 27 September 2017).

25. Phillips, W.; Lee, H.; James, P.; Ghobadian, A.; O'Regan, N. Social innovation and social entrepreneurship: A systematic review. Group Organ. Manag. 2015, 40, 428-461. [CrossRef]

26. Teece, D.J. Explicating dynamic capabilities: The nature and microfoundations of (sustainable) enterprise performance. Strateg. Manag. J. 2007, 28, 1319-1350. [CrossRef]

27. Rebelo, T.M.; Gomes, A.D. Organizational learning and the learning organization. Reviewing evolution for prospecting the future. Learn. Organ. 2008, 15, 294-308. [CrossRef]

28. Chu, M.-T.; Fardoei, S.R.; Fallah, H.; Ghazinoory, S.; Aliahmadi, A. Modeling national innovation system enabled by knowledge management. J. Bus. Econ. Manag. 2014, 15, 964-977. [CrossRef]

29. Dixon, N.M. Organizational learning: A review of literature with implications for HRD professionals. Hum. Resour. Dev. Q. 1992, 3, 29-49. [CrossRef]

30. Huber, G.P. Organizational learning: The contributing processes and the literatures. Organ. Sci. 1991, 2, 88-115. [CrossRef]

31. Jerez-Gómez, P.; Céspedes-Lorente, J.; Valle-Cabrera, R. Organizational learning capability: A proposal of measurement. J. Bus. Res. 2005, 58, 715-725. [CrossRef]

32. Pérez, S.; Montes, J.M.; Vázquez, C. Measuring organisational learning: Proposal of a multidimensional scale. Int. J. Learn. Intellect. Cap. 2007, 4, 276-293.

33. Hurrell, S.A.; Warhurst, C.; Nickson, D. Giving Miss Marple a makeover: Graduate recruitment, systems failure, and the Scottish voluntary sector. Nonprofit Volunt. Sect. Q. 2011, 40, 336-355. [CrossRef]

34. Maier, F.; Meyer, M.; Steinbereithner, M. Nonprofit organizations becoming business-like: A systematic review. Nonprofit Volunt. Sect. Q. 2016, 45, 64-86. [CrossRef]

35. Dobrai, K.; Farkas, F. Nonprofit organizations from the perspective of organizational development and their influence on professionalization. Naše Gospod. Our Econ. 2016, 62, 25-32. [CrossRef]

36. Van Tulder, R.; Fortanier, F. Business and sustainable development: From passive involvement to active partnerships. In Doing Good or Doing Better. Development Policies in a Globalizing World; Kremer, M., van Lieshout, P., Went, R., Eds.; Scientific Council for Government Policy (WRR), Amsterdam University Press: Amsterdam, The Netherland, 2009; pp. 211-235.

37. Trumpy, A.J. Subject to negotiation: The mechanisms behind co-optation and corporate reform. Soc. Probl. 2008, 55, 480-500. [CrossRef]

38. Akgün, A.E.; Byrne, J.; Keskin, H.; Lynn, G.S.; Imamoglu, S.Z. Knowledge networks in new product development projects: A transactive memory perspective. Inf. Manag. 2005, 42, 1105-1120. [CrossRef]

39. Conner, M.L.; Clawson, J.G. (Eds.) Creating a Learning Culture: Strategy, Technology, and Practice; Cambridge University Press: Cambridge, UK, 2004; ISBN 0521830176.

40. Nonaka, I. A dynamic theory of organizational knowledge creation. Organ. Sci. 1994, 5, 14-37. [CrossRef]

41. Prugsamatz, R. Factors that influence organization learning sustainability in non-profit organizations. Learn. Organ. 2010, 17, 243-267. [CrossRef]

42. Bennett, R.; Mousley, W.; Ali-Choudhury, R. Transfer of marketing knowledge within business nonprofit collaborations. J. Nonprofit Public Sect. Mark. 2008, 20, 37-70. [CrossRef]

43. Barroso-Méndez, M.J.; Galera-Casquet, C.; Valero-Amaro, V. Proposal of a social alliance success model from a relationship marketing perspective: A meta-analytical study of the theoretical foundations. BRQ-Bus. Res. Q. 2015, 18, 188-203. [CrossRef]

44. Seitanidi, M.M.; Crane, A. Implementing CSR through partnerships: Understanding the selection, design and institutionalisation of nonprofit-business partnerships. J. Bus. Ethics 2009, 85, 413-429. [CrossRef]

45. Berger, I.E.; Cunningham, P.H.; Drumwright, M.E. Identity, identification and relationship through social alliances. J. Acad. Mark. Sci. 2006, 34, 128-137. [CrossRef]

46. Bryson, J.M.; Crosby, B.C.; Middleton Stone, M. The design and implementation of cross-sector collaborations: Propositions from the literature. Public Adm. Rev. 2006, 66, 44-55. [CrossRef]

47. Campbell, D.; Slack, R. Public visibility as a determinant of the rate of corporate charitable donations. Bus. Ethics 2006, 15, 19-28. [CrossRef]

48. Hwang, H.; Powell, W.W. The rationalization of charity: The influences of professionalism in the nonprofit sector. Adm. Sci. Q. 2009, 54, 268-298. [CrossRef] 
49. Randle, M.; Dolnicar, S. Self-congruity and volunteering: A multi-organisation comparison. Eur. J. Mark. 2011, 45, 739-758. [CrossRef]

50. Handy, F.; Mook, L.; Quarter, J. The interchangeability of paid staff and volunteers in nonprofit organizations. Nonprofit Volunt. Sect. Q. 2008, 37, 76-92. [CrossRef]

51. Al-Zu'bi, H.A. A study of relationship between organizational justice and job satisfaction. Int. J. Bus. Manag. 2010, 5, 102-109. [CrossRef]

52. Ybema, J.F.; Van den Bos, K. Effects of organizational justice on depressive symptoms and sickness absence: A longitudinal perspective. Soc. Sci. Med. 2010, 70, 1609-1617. [CrossRef] [PubMed]

53. Youssef, C.M.; Luthans, F. Positive organizational behavior in the workplace: The impact of hope, optimism, and resilience. J. Manag. 2007, 33, 774-800. [CrossRef]

54. Boezeman, E.J.; Ellemers, N. Pride and respect in volunteers' organizational commitment. Eur. J. Soc. Psychol. 2008, 38, 159-172. [CrossRef]

55. Galindo-Kuhn, R.; Guzley, R.M. The volunteer satisfaction index: Construct definition, measurement, development, and validation. J. Soc. Serv. Res. 2001, 28, 45-68. [CrossRef]

56. Garner, J.T.; Garner, L.T. Volunteering an opinion: Organizational voice and volunteer retention in nonprofit organizations. Nonprofit Volunt. Sect. Q. 2011, 40, 813-828. [CrossRef]

57. Hopt, K.J.; Walz, W.R.; Von Hippel, T.; Then, V. (Eds.) The European Foundation. A New Legal Approach; Cambridge University Press: Cambridge, UK, 2006; ISBN 05218633339780521863339.

58. European Foundation Centre. European Foundation Statute State of Play; EESC-Social Economy Category Meeting. 2015. Available online: http://www.eesc.europa.eu/resources/docs/european-foundationcentre.pdf (accessed on 14 July 2017).

59. Ashley, S.; Faulk, L. Nonprofit competition in the grants marketplace. Exploring the relationship between nonprofit financial ratios and grant amount. Nonprofit Manag. Lead. 2010, 21, 43-57. [CrossRef]

60. European Foundation Centre (EFC); Donors and Foundations Networks in Europe (DAFNE). Exploring Transparency and Accountability Regulation of Public-Benefit Foundations in Europe; European Foundation Centre: Bruxelles, Belgium, 2011.

61. Rey-García, M.; Álvarez-González, L.I. El Sector Fundacional Español. Datos Básicos; Asociación Española de Fundaciones: Madrid, Spain, 2011.

62. Podsakoff, P.M.; MacKenzie, S.B.; Lee, J.Y.; Podsakoff, N.P. Common method biases in behavioural research: A critical review of the literature and recommended remedies. J. Appl. Psychol. 2003, 88, 879-903. [CrossRef] [PubMed]

63. Armstrong, J.S.; Overton, T.S. Estimating nonresponse bias in mail surveys. J. Mark. Res. 1977, 14, $396-402$. [CrossRef]

64. Groves, R.M. Nonresponse rates and nonresponse bias in household surveys. Public Opin. Q. 2006, 70, 646-675. [CrossRef]

65. Darroch, J. Knowledge management, innovation and firm performance. J. Knowl. Manag. 2005, 9, $101-115$. [CrossRef]

66. Weerawardena, J.; Cass, A.; Julian, C. Does industry matter? Examining the role of industry structure and organizational learning in innovation and brand performance. J. Bus. Res. 2006, 59, 37-45. [CrossRef]

67. Bakker, M.; Leenders, T.A.J.; Gabbay, S.M.; Kratzer, J.; Van Engelen, J.M.L. Is trust really social capital? Knowledge sharing in product development projects. Learn. Organ. 2006, 13, 594-605. [CrossRef]

68. Morgan, R.M.; Hunt, S.D. The commitment-trust theory of relationship marketing. J. Mark. 1994, 58, $20-38$. [CrossRef]

69. Gounaris, S.P. Internal-market orientation and its measurement. J. Bus. Res. 2006, 59, 432-448. [CrossRef]

70. Marano, V.; Tashman, P. MNE/NGO partnerships and the legitimacy of the firm. Int. Bus. Rev. 2012, 2, 1122-1130. [CrossRef]

71. Rundall, P. The perils of partnership-An NGO perspective. Addiction 2000, 95, 1501-1504. [CrossRef] [PubMed]

72. Wymer, W.W.; Samu, S. Dimensions of business and nonprofit collaborative relationships. J. Nonprofit Public Sect. Mark. 2003, 11, 3-22. [CrossRef]

73. Boateng, A.; Akamavi, R.K.; Ndoro, G. Measuring performance of non-profit organisations: Evidence from large charities. Bus. Ethics 2016, 25, 59-74. [CrossRef] 
74. Weerawardena, J.; Sullivan Mort, G. Learning, innovation and competitive advantage in not-for-profit aged care marketing: A conceptual model and research propositions. J. Nonprofit Public Sect. Mark. 2001, 9, 53-73. [CrossRef]

75. Spicer, D.P.; Sadler-Smith, E. Organizational learning in smaller manufacturing firms. Int. Small Bus. J. 2006, 24, 133-158. [CrossRef]

76. Seitanidi, M.M.; Koufopoulos, D.; Palmer, P. Partnership formation for change: Indicators for transformative potential in cross sector social partnerships. J. Bus. Ethics 2010, 94, 139-161. [CrossRef]

77. European Commission. Communication from the Commission to the European Parliament, the Council, the European Economic and Social Committee and the Committee of the Regions: Europe 2020 Flagship Initiative-Innovation Union; European Commission: Brussels, Belgium, 2010.

78. Bouchard, M.J. Social innovation, an analytical grid for understanding the social economy: The example of the Quebec housing sector. Serv. Bus. 2012, 6, 47-59. [CrossRef]

79. Committee Encouraging Corporate Philanthropy. Shaping the Future: Solving Social Problems through Business Strategy. Pathways to Sustainable Value Creation in 2020; Committee Encouraging Corporate Philanthropy New York: New York, NY, USA, 2010.

80. Brunner, C.; Marxt, C. Non-governmental organizations (NGO) and businesses in joint product innovation -Development of a theoretical framework for "green" products. Int. J. Innov. Sustain. Dev. 2013, 7, 192-211. [CrossRef]

81. Dahan, N.M.; Doh, J.P.; Oetzel, J.; Yaziji, M. Corporate-NGO collaboration: Cocreating new business models for developing markets. Long Range Plan. 2010, 43, 326-342. [CrossRef]

82. Holmes, S.; Smart, P. Exploring open innovation practice in firm-nonprofit engagements: A corporate social responsibility perspective. RED Manag. 2009, 39, 394-409.

83. Ljung, A.; Bengtson, A. Innovation through business and NGO co-operation: The case of digital inclusion in the Amazon. In Business, Society and Politics (International Business and Management, Volume 28); Hadjikhani, A., Elg, U., Ghauri, P., Eds.; Emerald Group Publishing Limited: Bingley, UK, 2012; pp. 281-301. 